\title{
Leucocyte and erythrocyte chimerism in heterosexual bovine quadruplets
}

\author{
Hiroshi Kanagawa, Suezo Kosaka*, Tatuo Hosoda** and Tsune Ishikawa \\ (Department of Veterinary Obstetrics, Faculty of Veterinary Medicine, \\ Hokkaido University, Sapporo. *Laboratory of Zootechnical Science, \\ Faculty of Agriculture, Yamagata University, Tsuruoka. ${ }^{* *}$ National \\ Institute of Animal Industry, Chiba, Japan.)
}

(Received for Publication on December 14, 1968)

Since Owen's (1945) discovery of erythrocyte chimerism in heterosexual bovine twins, several investigators reported the co-existence of male and female cells among the leucocytes of these cattle (Ohno et al., 1962; Fechietmer et al., 1963; Goodfellow et al., 1965; Kanagawa et al., $1965 \mathrm{~b}$; BASRUR and STOLTz, 1966). However, a majority of these reports are limited to chimerism in either erythrocytes (Owen, 1945: Rendel et al., 1962; Stone and CRagle, 1964) or leucocytes (Kanagawa et al., 1965 b; MCFeely et al., 1967; Basrur and Kanagawa, 1969), and in a few instances in germ cells (OhNo et al., 1962; Ohno and Gropp, 1965; Kanagawa et al., 1965 b; Teplitz et al., 1967). The present report concerns a comparative analysis of erythrocyte antigens and cytological sex of cultured leucocytes in heterosexual quadruplets.

\section{Materials and Methods}

A 10.5-year-old Holstein cow gave premature birth to a litter of four, three freemartins and one male. They were calved about 19 days earlier than expected, but were all healthy (Service date of August 25, 1955. Birth date of May 12, 1966). Their sire and dam were registered as Holstein Herd Book Registry-No. 35001, and as Holstein Supplementary Registry-No. KFS 571594, respectively.

Blood samples for the examination of leucocytes and erythrocytes were obtained from the jugular vein when the quadruplets were 13 days. Chromosome study was carried out on leucocyte cultures according to the method described previously (KANAGAwa et al., 1965 b). Blood type analysis was based on the method of standard hemolytic test partly modified by KOSAKA et al., (1967).

Three of the quadruplets were sacrificed at the age of one month, and the gross morphology and the microscopic features of the reproductive organs were observed. The remaining calf is still under observation.

\section{Results}

Table 1 presents the chromosome findings on cultured leucocytes and the pattern of erythrocyte antigens in quadruplets. Chimerism for male and female cells was noted in all 4 calves. The ratio of male and female cells are seemed to be approximately similar in all calves irrespective to their phenotypic sex, the XX cells being the highest, ranging from 93.2 to $95.7 \%$. 
On the other hand, erythrocytes appeared to consist of 4 different genotype, $A_{1} /-; A_{2} /-; A_{1} / A_{2}$; $-/-$ in $A$ system and $\mathrm{GY}_{2} \mathrm{E}_{3}^{\prime} / \mathrm{Y}_{1} ; \mathrm{GY}_{2} \mathrm{E}_{2}^{\prime}{ }_{2} / \mathrm{E}^{\prime}{ }_{8} \mathrm{O}^{\prime}{ }_{2} \mathrm{Y}_{1}^{\prime} ; \mathrm{O}_{8} \mathrm{~J}^{\prime} \mathrm{K}^{\prime} \mathrm{O}_{2}^{\prime} / \mathrm{Y}_{1} ; \mathrm{O}_{8} \mathrm{~J}^{\prime} \mathrm{K}^{\prime} \mathrm{O}^{\prime}{ }_{2} / \mathrm{E}^{\prime}{ }_{3} \mathrm{O}^{\prime}{ }_{2} \mathrm{Y}^{\prime}{ }_{1}$ in $\mathrm{B}$, showing a state of quadruple chimerism. In other systems, reaction was seen $\mathrm{L}, \mathrm{S}-\mathrm{U}$ and $Z$, whereas tests for $J$ were negative in all calves. Although the analysis of red cell antigens immunogenetically insufficient in $C, C_{1}$ and $W_{1}$ antigen showed partial hemolysis.

Table 1. Chimerism in leukocytes and erythrocytes of bovine quadruplet

\begin{tabular}{|c|c|c|c|c|c|c|c|c|c|c|c|}
\hline \multirow{2}{*}{ Sex. } & \multicolumn{2}{|c|}{ Sex chromosome } & \multicolumn{9}{|c|}{ Blood type system } \\
\hline & $\mathrm{XX}(\%)$ & $\mathrm{XY}(\%)$ & A & B & $\mathrm{C}$ & $\mathrm{F}-\mathrm{V}$ & J & $\mathbf{L}$ & S-U & $\mathbf{z}$ & $\mathbf{R}^{\prime}-\mathbf{S}^{\prime}$ \\
\hline Female \#1 & $130(95.6)$ & $6(4.4)$ & $A_{1} / \ldots$ & $G Y_{2} E_{2}^{\prime} / Y_{1}$ & $W_{1} / C X_{1}$ & $F / F$ & $-1-$ & $\mathrm{L} / \mathrm{H}$ & $\mathrm{H}^{\prime} /-$ & $Z /-$ & $s^{\prime} / s^{\prime}-1$ \\
\hline Female $\sharp 2$ & $120(94.5)$ & $7(5.5)$ & $\mathrm{A}_{2} /-$ & $\mathrm{GY}_{2} \mathrm{E}_{2}^{\prime}{ }_{2} / \mathrm{E}^{\prime}{ }_{8} \mathrm{O}_{2}^{\prime} \mathrm{Y}_{1}^{\prime}{ }_{1}$ & $\mathrm{CX}_{1 /}-$ & $F / F$ & $-1-$ & $\mathrm{L} /-$ & $\mathrm{H}^{\prime} /-$ & $-1-$ & $\mathbf{S}^{\prime} / \mathbf{S}^{\prime}$ \\
\hline Male $\sharp 3$ & $124(93.2)$ & $9(6.8)$ & $A_{1} / A_{2}$ & $\mathrm{O}_{3} \mathrm{~J}^{\prime} \mathrm{K}^{\prime} \mathrm{O}_{2}^{\prime} / \mathrm{Y}_{1}$ & $\mathrm{X}_{2} / \mathrm{W}_{1}$ & $F / F$ & $-1-$ & $\mathrm{L} /-$ & $-1-$ & $-1-$ & $\mathbf{S}^{\prime} / \mathbf{S}^{\prime}$ \\
\hline Female $\sharp 4$ & $200(95.7)$ & $9(4.3)$ & $-1-$ & $\mathrm{E}^{\prime}{ }_{8} \mathrm{O}^{\prime}{ }_{2} \mathrm{Y}^{\prime}{ }_{1} / \mathrm{O}_{3} \mathrm{~J}^{\prime} \mathrm{K}^{\prime} \mathrm{O}^{\prime}{ }_{2}$ & $\mathrm{X}_{2} /-$ & $F / F$ & $-1-$ & $-1-$ & $-1-$ & $-1-$ & $\mathbf{S}^{\prime} / \mathbf{S}^{\prime}$ \\
\hline Sire & * & * & $\mathrm{A}_{2} /-$ & $\mathrm{GY}_{2} \mathrm{E}_{2}^{\prime} / \mathrm{O}_{3} \mathrm{~J}^{\prime} \mathrm{K}^{\prime} \mathrm{O}_{3}^{\prime}$ & $W_{1} /-$ & $F / F$ & $-1-$ & $-1-$ & $\mathrm{H}^{\prime} /-$ & $z /-$ & $\mathbf{S}^{\prime} / \mathbf{S}^{\prime}$ \\
\hline Dam & * & * & $\mathrm{A}_{1} /-$ & $\mathrm{Y}_{1} / \mathrm{E}^{\prime}{ }_{8} \mathrm{O}_{2} \mathrm{Y}_{1}^{\prime}$ & $c X_{1} / X_{2}$ & $F / F$ & $\mathrm{~J}^{c s_{1}}-$ & $\mathrm{L} /-$ & $\mathbf{H}^{\prime} /-$ & $-1-$ & $\mathbf{S}^{\prime} / \mathbf{S}^{\prime}$ \\
\hline
\end{tabular}

* Chromosomes were not examined

[]Quadruple chimerism

Macroscopical appearances of the sexual organs of 2 freemartins are shown in figures 2 and 3. In both cases, several typical morphological characteristics of freemartin were observed: absence of the oviduct and cervix, the hypoplastic uterus and anterior vagina, the overdeveloped clitoris, the presence of the seminal vesicle-like structures, rudimentary structures of the Wolffian ducts and the well-developed ovarian blood vessel plexuses.

Histologically, the bilaterial gonads in both cases showed immature ovary of a normal heifer but failed to show structures resembling seminiferous tubules. However, in both cases, at the surrounding portion of the rete ovarii, there existed a mass of small tubes somewhat resembling immature seminiferous tubules. In the uterine horns and seminal vesicle-like structures in both freemartins, undeveloped gland-like structures were observed in the tunica propria. The rudimentary Wolffian ducts had a central cavity and the surrounding portion containing small gland-like structures scattered here and there.

\section{Discussion}

Members of the same litter generally show a similar ratio of mixing of leucocytes and erythrocytes in cattle (BASRUR and Kanagawa, 1969). The pattern of chimerism in leucocytes, appears to be similar during the development despite the difference in the cell type analysed. The occurrence of chimerisms and the absence of fluctuation of sex ratio among the cells might be either due to the difference in the stage of development at which the shift of primordial germ cells (OHNo and GRoPP, 1965) and primordial hematopoietic cell (OWEN, 1945; OWEN et $a l .$, 1946) took place. Alternatively, it may be attributable to the quantitative relationship of transplanted cells, or due to the early selection of donor or host cells in the recipient gonad or blood forming tissue. The answer will not be obtained until a successful analysis of chromosomes in the gonads of chimeric cattle is accomplished. Kanagawa et al., (1965 a) and KANAGAWA and BASRUR (1968), have reported that early diagnosis of bovine freemartinism is possible through the leucocyte culture technique which replies on the morphology of sex chromosomes. The chimeric ratios in this study were remarkably parallel with each other in the 
Chimerism in heterosexual bovine quadruplets

members of each set of litter mates. Histologic characteristics of the gonads of 2 freemartins in quadruplets revealed resemblance to immature ovaries and the rate of the percentages of XX cells in these animals were high. The degree of histologic deviation in freemartin gonad does seem to depend upon the ratio of male cells in freemartins (Herschler and FechHzimer, 1967). Herschler and FeChHeimer (1967) have reported that the primary etiological factor of gonadal modification in freemartin is probably the $\mathrm{Y}$ chromosome-bearing cells at the time of differentiation. The mechanisms involved in the selection or rejection of cell types, which interchanged during embryonic growth and "homing" in different tissues of the hosts, are at present not really known.

\section{Summary}

Chromosome analysis from cultured leucocytes and blood type analysis from erythrocytes were carried out in heterosexual bovine quadruplets. Chimerism for male and female cells in the cultured leucocytes of quadruplets were observed. The ratio of male and female cells being approximately similar in members of sets. Also, erythrocytes appeared to consist of 4 different genotypes in A and B system, showing a state of quadruple chimerism in quadruplets.

\section{Acknowledgements}

We wish to thank Prof. Y. ARIMori, of the Department of Agriculture, Yamagata University, for reviewing and improving this manuscipt, and also Dr. S. MAsuda, of Holstein Cattle Association of Japan, and Prof. W.H. STone, of the Department of Genetics, University of Wisconsin, for their valuable suggestions and criticisms throughout the present work.

\section{References}

1) Basrur, P.K., and J.P.W. Gilman (1964) Nature, 204, 1335-1337.

2) BasRur, P.K., and H. Kanagawa (1969) In preparation.

3) BaSRUR, P.K., and D.R. Stoltz (1966) Chromosoma 19, 176-187.

4) Fechheimer, N.S., M.S. Herschler and L.O. Gilmore (1963) Proc. XI th Internat. Congress of Genetics. 1.

5) Goodfellow, S.A., S.J. Strong and J.S.S. Stewart (1965) Bovine freemartins and true hermaphroditism. Lancet, May 15; 1040-1041.

6) Herschler, M.S., and N.S. FechHeimer (1967) Cytogenetics 6, 204-212.

7) Kanagawa, H. and P.K. Basrur (1968) Can. J. Comp. Med. 32, 583-586.

8) Kanagawa, H., K. Kawata and T. Ishikawa (1965 a) Jap. J. Vet. Res. 13, 43-50.

9) Kanagawa, H., J. Muramoto, K. Kawata and T. Ishikawa (1965 b) Ibid. 13, 33-42.

10) Kosaka, S., H. Kanagawa and S. Nishida (1967) Tohoku J. Agr. Res. 18, 207-216.

11) MCfeely, R.A., W.C.D. Hare and J.D. Biggers (1967) Cytogenetics. 6, 242-253.

12) Ohno, S., J.M. Trujillo, C. Stenieus., L.C. Christian and R.L. Teplitz (1962) Cytogenetics $1,258-265$.

13) OhNo, S. and A. Gropp (1965) Ibid. 4, 251-260.

14) OWEN, R.D. (1945) Science 102, 400-401.

15) Owen, R.D., H.P. Davis and R.F. Morgan (1946) J. Hered. 37, 291-297.

16) Rendel, J., B. Gahne and K. Maijala (1962) Hereditas 48, 201-214.

17) Stone, W.H., and R.G. Cragle (1964) Science 146, 430-431.

18) Teplitz, R.L., Y.S. Moon and P.K. Basrur (1967) Chromosoma 22, 202-209. 


\title{
牛異性四仔における白血球と赤血球のキメラ
}

\author{
金川弘司・小坂末蔵*・細田達雄**.石川恒 \\ (北海道大学獣医学部, *山形大学農学部, **農林省畜産試験場)
}

異性双仔間の胎生期における血管吻合の結果生じる $2 \cdot 3$ の細胞のキメラ現象は, 赤血球においては表面の血 液型抗原を支配する遗伝子レベルで，白血球においては 染色体の楧成差 (る2 A-XY, 年 $2 \mathrm{~A}-\mathrm{XX})$ から，それぞ れ分析されフリーマーチンの早期䛦断に利用されるよう になっている.しかし，双仔以上の多胎については，白 血球と赤血球の䦥連・キメラの形・キメラ体の繁殖性な どにおいて不明確な点が多い。

本害験は雄 1 例・フリーマーチン3 例からなる異性四 仔について，白血球と赤血球のキメラの比䩙・キメラの 構造および程度・倠子のフリーマーチン化の程度などの 分析を行なったものである.白血球の培養は $37^{\circ} \mathrm{C} \cdot 72 \sim$ 96 時間・コルヒチン処理・水処理・カルノフ液固定後, 細胞浮遊液の空気乾燥による染绝体標本の作製を行な い,ギムザ液染色を旅し個々の細胞の性染色体を観察し た. 赤血球は $\mathrm{A} \cdot \mathrm{B} \cdot \mathrm{C} \cdot \mathrm{F}-\mathrm{V} \cdot \mathrm{J} \cdot \mathrm{L} \cdot \mathrm{S}-\mathrm{U} \cdot \mathrm{Z} \cdot \mathrm{R}^{\prime}-\mathrm{S}^{\prime}$ の 9 Blood Type System の遺伝子分析を行なったもの である.

その結果,

1. 白血球においては各仔共に 100 個以上の細胞の性
染色体を分析した結果，雌型細胞 (2A-XX) 百分等て 表示する場合，\#1()；95.6・\#2(ㅇ)；94.5-\#3(乃)； 93.2 ・\# 4 (ㅇ)；95.7 を示す $2 \mathrm{~A}-\mathrm{XX}$ と雄型細胞 $(2 \mathrm{~A}-$ $\mathrm{XY}$ )のキメラがみられ，四仔の此雄に関倸なくほとえど 同率に分布していることが明らかにされた。

2. 血液型反応においては各血球共に部分溶血を同程 度に示しており，血液型の四重キメラを推定し得る。す なわち, A System では $A_{1} /-+A_{2} /-+A_{1} / A_{2}+-/-, B$ Systemでは $\mathrm{GY}_{2} \mathrm{E}_{2}{ }_{2} / \mathrm{Y}_{1}+\mathrm{GY}_{2} \mathrm{E}_{2}^{\prime}{ }_{2} / \mathrm{E}^{\prime}{ }_{3} \mathrm{O}^{\prime}{ }_{2} \mathrm{Y}_{1}^{\prime}{ }_{1}+\mathrm{O}_{3} \mathrm{~J}^{\prime} \mathrm{K}^{\prime} \mathrm{O}_{2}{ }_{2}$ $\mathrm{Y}_{1}+\mathrm{O}_{3} \mathrm{~J}^{\prime} \mathrm{K}^{\prime} \mathrm{O}^{\prime}{ }_{2} / \mathrm{E}^{\prime}{ }_{3} \mathrm{O}^{\prime}{ }_{2} \mathrm{Y}^{\prime}{ }_{1}$ 它推定させるキメ 血がみられた，その他の L・S-U・Z およびC System に拉いてもキメラが証明された。

3. 四仔の中 井4 莸除き屠殺解体されたが，異性双任 のフリーマーチンと同じく，幼若精露の出現，子宮体部 の欠除，ピーナッッ大に退化した子宮角・痕跡的存在の 卵栄部が特徵的变状であり，組緎学的には子宮角の腺は 著しく乏しく，性腺においては幼若卵巣の所見がみられ

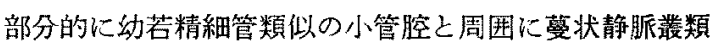
似のよく発達した血管菜がみられれ。雄仔は正常の生殖 器, 副生殖器を有していることが確認された。

\section{Plate}

Fig. 1. Frontal views of a set of heterosexual quadruplets. Nos. 1,2 and 4 are freemartins, and No. 3 is a male.

Figs. 2 and 3 .

A general appearance of reproductive organs from freemartins (Fig. 2: case \#1 and Fig.

3 : case $\# 2$ ). Arrows indicate the sites of gonads (scale: $\mathrm{cm}$ ).

Figs. 4 and 5 .

Metaphase chromosomes from leucocyte cultures of a freemartin (case \#1), showing $\mathrm{XX} / \mathrm{XY}$ chimerism. Giemsa stain. X 2,000. Fig. 4: A metaphase plate showing the female bovine complement including two submetacentric $X$ chromosomes. Arrows indicate sex chromosomes. Fig. 5: The same, showing the male bovine complement. Note one large submetacentric $\mathrm{X}$ chromosome and a small metacentric $\mathrm{Y}$ chromosome. Arrows show $\mathrm{X}$ and $\mathrm{Y}$, respectively. The bovine autosomes are all acrocentric. 
Chimerism in heterosexual bovine quadruplets

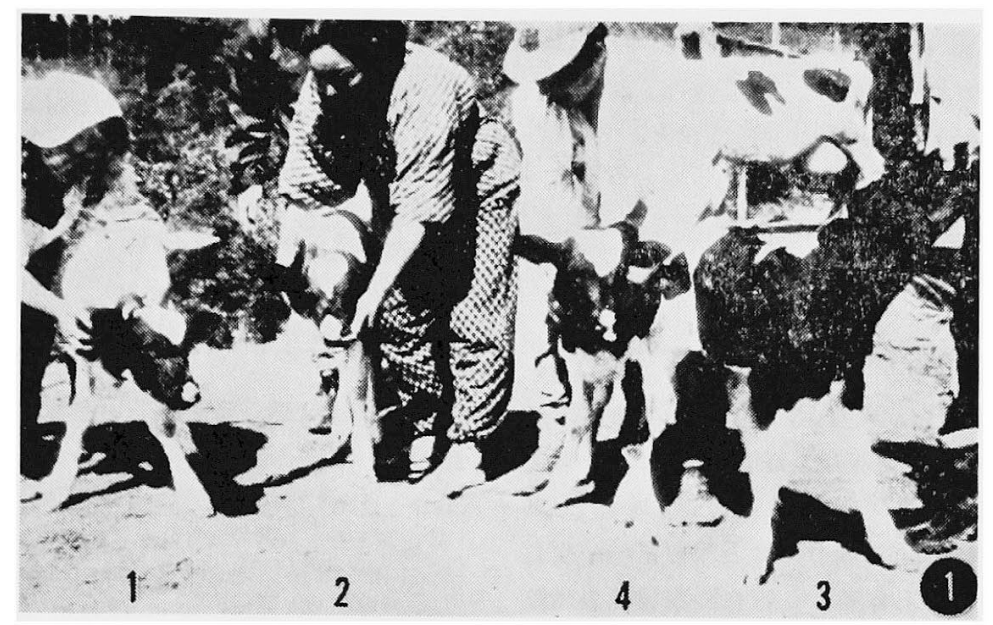

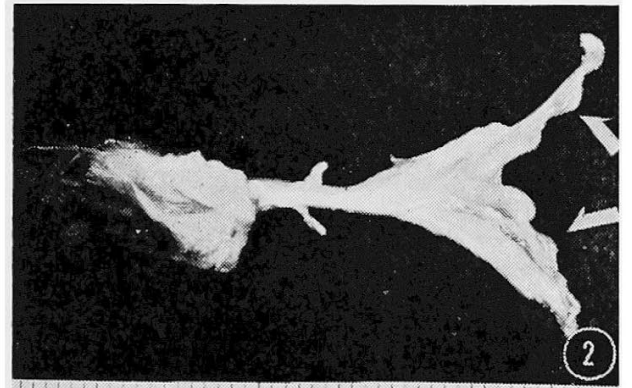

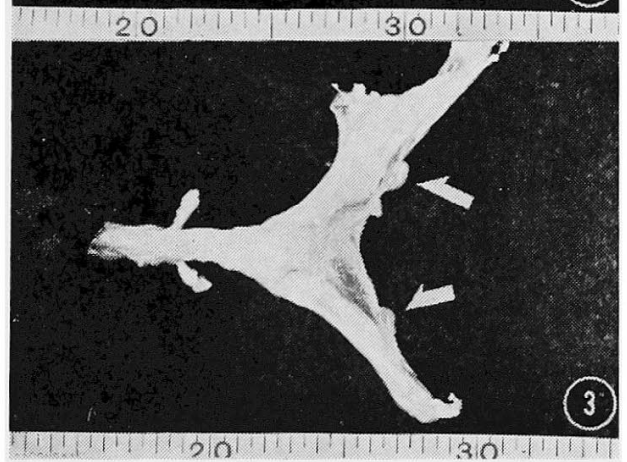

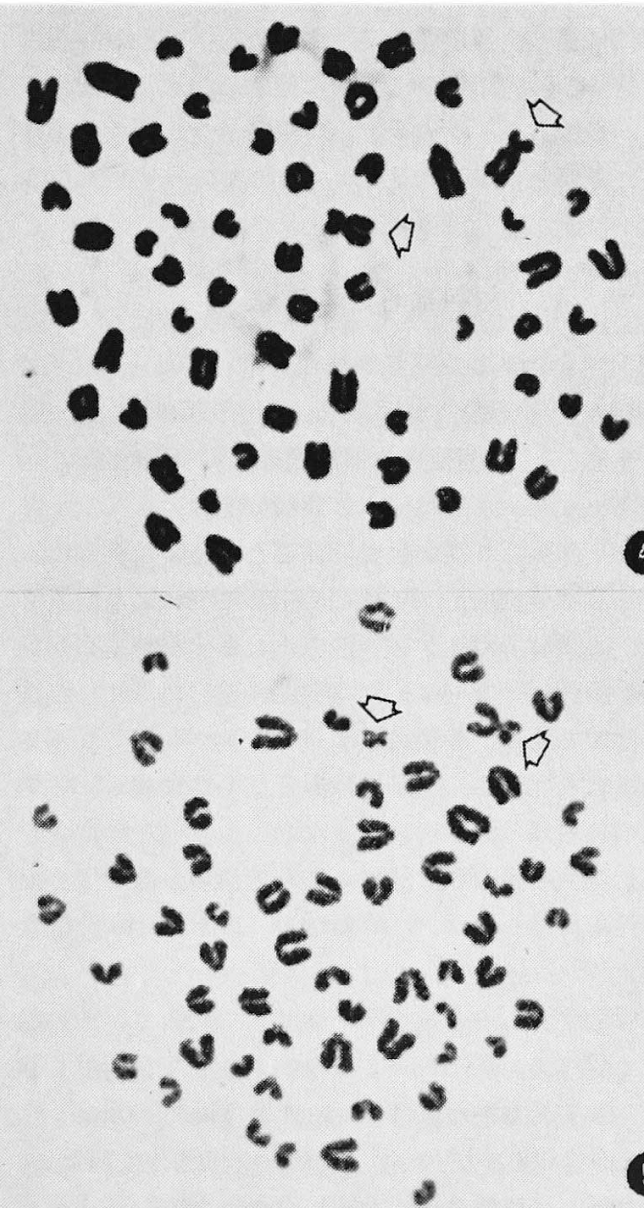

(4) 